\title{
PENDIDIKAN ISLAM DAN GLOBALISASI
}

\section{Oleh : Mulyadi ${ }^{54}$}

\begin{abstract}
Abstrak
Hadirnya globalisasi dalam kehidupan pribadi dan sosial kita, maka setiap perjalanan hidup kita akan dipaksa menerima warna globalisasi. Tidak terkecuali dengan sistem pendidikan Islam di era modern ini. Pendidikan Islam dihadapkan pada berbagai persoalan yang memberikan dampak yang cukup signifikan terhadap produk output pendidikan Islam. Di antara tantangan yang kelihatan jelas adalah konformisme, dikotomi IMTAQ dan IPTEK, dekadensi moral dan sebagainya.Untuk itu perlu bagi pendidikan Islam untuk kembali memperkuat sistem pendidikan Islam baik secara konseptual maupun praktis. Secara konseptual harus dimulai dengan kembali secara utuh kepada ajaran agama yang mengajak umatnya untuk selalu mengoptimalkan akal, menjaga keseimbangan antara wahyu danakal, kembali kepada universalitas Islam dengan membentukkombinasi yang baik antara kehidupan pribadi, sosial dan alam.
\end{abstract}

\section{Kata Kunci : Pendidikan Islam, Globalisasi}

\section{Pendahuluan}

Optimalisasi pendidikan sebagai usaha pengembangan potensi diri melalui proses pembelajaran atau cara lain yang dikenal dan diakui oleh masyarakat dan berlandaskan pada ajaran agama harus selalu ditingkatkan, terlebih pada era globalisasi seperti saat ini. Hal itu dimaksudkan untuk menyelesaikan permasalahan-permasalah pendidikan yang dihadapi di era globalisasi ini. Baik itu masalah yang bersifat internal maupun eksternal.

Jurnal ini berusaha mengidentifikasi dan memahamkan permasalahan pendidikan Islam di era globalisasi dan bagaimana seharusnya

\footnotetext{
${ }^{54}$ Dosen Tetap Program Studi Pendidikan Agama Islam STAI Auliaurrasyidin Tembilahan Kabupaten Indragiri Hilir Propinsi Riau.
}

54 
pendidikan Islam menyikapinya agar tidak masuk lebih dalam ke dalam pengaruh globalisasi.

\section{Pengertian Globalisasi}

Secara etimologi, Globalisasi ialah seluruhnya dan menyeluruh. Sedangkan secara terminologi, globalisasi ialah pengglobalan secara keseluruhan aspek kehidupan, perwujudan (peningkatan/perubahan) secara menyeluruh disegala aspek kehidupan. Kemudian membaca pengertian secara luas, globalisasi adalah proses pertumbuhan negara-negara maju seperti halnya Amerika, Eropa dan Jepang, yang telah melakukan ekspansi besar-besaran. Kemudian berusaha men-dominasi dan merubah dunia dengan kekuatan teknologi, ilmu pengetahuan, politik, budaya, militer, ekonomi, dan pendidikan. ${ }^{55}$

Menurut David Held dan Anthony Mc Grew, tidak ada devinisi "globalisasi" yang tepat yang disepakati bersama. Globalisasi dapat dipahami dalam pemahaman yang beragam sebagai kedekatan jarak, ruangan waktu yang menyempit, pengaruh yang cepat, dan dunia yang menyempit, perbedaanya hanya terletak pada penekanan dari sudut pandang material, ruangan dan waktu, serta aspek-aspek kognitif dari globalisasi. Dari sudut peristilahan, kata "globalisasi" sebenarnya masih mengalami problem karena realitas serta subyektifitas pemakaian kata tersebut, namun "globalisasi" secara sederhana dapat ditunjukkan dalam bentuk perluasan skala, pengembangan wilayah, dan percepatan pengaruh dari arus dan polapola inter-regional dalam interaksi sosial. ${ }^{56}$

Globalisasi merupakan suatu proses pengintegrasian ekonomi nasional bangsa-bangsa ke dalam suatu sistem ekonomi global. Ia juga

${ }^{55}$ Arif Shaifudin, "Peran Strategis Pendidikan Islam di Era Globalisasi". AlHikmah Jurnal Studi Islam. Vol. 6 No. 2 2016, h. 222-223.

${ }^{56}$ Ibid, h. 223. 
merupakan proses kebudayaan yang ditandai dengan adanya kecenderungan wilayah-wilayah di dunia, baik geografis maupun fisik, menjadi seragam dalam format sosial, budaya, ekonomi, dan politik. Dalam kehidupan sosial, proses global telah menciptakan egalitarianisme, di bidang budaya memicu munculnya internationalization of culture, di bidang ekonomi menciptakan salingketergantungan dalam proses produksi dan pemasaran, dan di bidang politik menciptakan liberalisasi.

Meskipun globalisasi dikampanyekan sebagai eramasa depan, yakni suatu era yang menjanjikan pertumbuhan ekonomi secara global dan akan mendatangkan kemakmuran global bagi semua. ${ }^{57}$ Sedangkan kata modern, modernitas, modernisme dan modernisasi berasal dari asal kata yang sama yaitu Modernus (latin) yang artiya "baru saja, just now, atau terkini, sikap dan cara berfikir serta cara bertindak sesuai dengan tuntutan zaman, akan tetapi adanya tambahan atau imbuhan yang ada pada ujung kata tersebut menjadikannya mengalami sedikit perubahan artian. ${ }^{58}$

Modernisasi dapat diartikan sebagai gerakan, aliran atau usahausaha yang bertujuan menafsirkan kembali doktrin-doktrin tradisional, dan menyesuaikannya dengan perkembangan zaman dan ilmu pengetahuan. Lebih jauh dijelaskan bahwa modernisasi adalah suatu pemahaman yang diidentikkan dengan pengertian rasionalisasi, karena rasionalisasi ini berarti suatu proses yang mengubah pola dan tata cara berfikir yang bersifat tradisional (tidak akliah) menjadi tata cara dan pola yang lebih maju dan modern (rasional). ${ }^{59}$

${ }^{57}$ M. Ali Sibram Malisi, “Tantangan dan Peluang Pendidikan Islam di Era MEA". Jurnal Transformatif (Islamic Studies). Vol. 1 No. 1 2017, h. 1-2.

${ }^{58}$ Nurcholish Madjid. Islam Doktrin dan Peradaban; Sebuah Telaah Kritis Tentang Masalah Ketuhanan, Kemanusiaan, dan keindonesiaan.Jakarta: Paradima. 1992. h. 446 .

${ }^{59}$ Nurcholish Madjid. Islam dan Kemodernan dan Keindonesiaan. Bandung: Mizan. 1987. h. 172. 
Sedangkan menurut Harun Nasution, Modernisasi mengandung arti pikiran, aliran, gerakan, dan usaha-usaha untuk mengubah paham-paham, adat istiadat, institusi-institusi lama dan lain sebagainya, agar semua itu menjadi sesuai dengan pendapat dan keadaan baru yang ditimbulkan oleh ilmu pengetahuan dan teknologi modern. ${ }^{60}$ Islam dan Modernisasi memang bukanlah suatu isu yang baru muncul dalam sejarah perkembangan pemikiran Islam, isu ini telah lama beredar dan telah banyak menyita perhatian para ilmuan dan cendikiawan, baik cendikiawan Islam maupun di luar Islam.

Globalisasi merupakan sebuah fenomena kompleks yang memiliki efek luas terhadap semua dimensi kehidupan umat manusia. Tidak mengherankan jika istilah"globalisasi" ini telah memperoleh konotasi arti yang cukup banyak. Di satu sisi, globalisasi dipandang sebagai kekuatan yang tak tertahankan serta jinak untuk memberikan kemakmuran ekonomi kepada orang-orang di seluruh dunia. Di sisi lain, ia dituding sebagai sumber dari segala penyakit kontemporer yang mematikan identitas budaya setiap bangsa. Dua sisi berbeda yang melekat pada globalisasi ini menjadi perhatian serius berbagai bangsa dalam mempertahankan karakter budayanya melalui dunia pendidikan. ${ }^{61}$

Pada era globalisasi seperti sekarang ini, bangsa Indonesia dihadapkan pada berbagai tantangan yang berskala global. Globalisasi tidak hanya menyebabkan terjadinya transformasi peradaban dunia melalui proses modernisasi, industrialisasi, dan revolusi informasi, tapi juga menimbulkan

${ }^{60}$ Harun Nasution. Islam Rasional Gagasan Dan Pemikiran. Bandung: Mizan. 1995. h. 181

${ }^{61}$ Arif Shaifudin, op. Cit., h. 219. 
perubahan dalam struktur kehidupan dalam berbagai bidang, baik dibidang sosial, budaya, ekonomi, politik maupun pendidikan. ${ }^{62}$

Globalisasi selain menghadirkan peluang "positif" untuk hidup mewah, nyaman, murah, indah, dan maju juga dapat menghadirkan peluang "negatif " yaitu menimbulkan keresahan, penyesalan, dan penderitaan. Globalisasi bekerja selama 24 jam dengan menawarkan banyak pilihan dan kebebasan yang bersifat pribadi. Pendek kata, dewasa ini telah terjadi "banjir pilihan dan peluang", terserah kemampuan seseorang memilikinya. U Thant, mantan sekjen PBB pada tahun 1672 menyatakan bahwa sumberdaya tidak lagi membatasi keputusan, tapi keputusanlah yang menciptakan sumberdaya. ${ }^{63}$

\section{Permasalahan Pendidikan Islam Di Era Globalisasi}

Usaha untuk mewujudkan generasi-generasi yang tangguh, kokoh, kaya, dan unggul tersebut tidaklah mudah, terutama pada era globalisasi seperti saat ini. Di mana globalisasi telah membawa wajah baru dalam proses ekspansi besar-besarannya dan berusaha mendominasi kekuatan teknologi, ilmu pengerahuan, politik, budaya, militer, dan ekonomi. Sehingga banyak permasalahan pendidikan yang muncul dan berkembang yang mampu menguatkan sistem pendidikan Islam dan melemahkan di sisi yang lain. Hal tersebut tidak lepas dari aspek positif dan negatif dari globalisasi itu sendiri. Ada beberapa permasalahan pendidikan Islam yang muncul dari adanya proses pertumbuhan dunia saat ini, di antaranya adalah:

\section{a. Konformisme}

Konformisme biasanya terjadi pada suatu kondisi yang sudah mapan (established) dan merambat dengan halus disetiap ranah kehidupan

${ }^{62}$ Ali Mahsun, "Pendidikan Islam dalam Arus Globalisasi; Sebuah Kajian Deskriptif Analitis”. Jurnal Episteme Vol. 8 No. 2 2013, 265-266.

${ }^{63}$ Ibid, h. 266. 
manusia, tidak terkecuali dunia pendidikan. Rasa cepat puas dengan keadaan yang sudah ada atau kemapanan dalam dunia pendidikan sering terjadi pada sistem pendidikan yang bergerak lambat, sehingga secara tidak langsung akan memperlambat gerakan system tersebut untuk maju. Keterlambatan gerak sistem tersebut akan mematikan segala daya upaya untuk berkembang dan berinovasi. ${ }^{64}$

Keadaan inilah yang biasanya disebut dengan konformisme, yaitu keadaan cepat merasa puas dengan keadaan yang ada. Konformisme merupakan tantangan pendidikan di manapun. Karena ia adalah musuh utama kreatifitas. Padahal, kreatifitas sangat dibutuhkan untuk terus memperbarui keadaan pendidikan. Jepang yang dikenal dengan sistem pendidikan yang ketat justru sejak 1980-an meninjau ulang pendidikan mereka yang dianggap terjebak konformitas. Kreatifitas yang merupakan "ruh" pendidikan dinilai sudah lama tercerabut sehingga hal itu sangat mengkhawatirkan pemerintah Jepang.

Bisa dibayangkan, implikasi lebih lanjut dari konformisme pendidikan Islam. Kurikulum yang kini dijalankan di lembaga pendidikan Islam, khususnya pada pendidikan dasar dan menengah, masih banyak menggunakan model lama. ${ }^{65}$

\section{b. Dikotomi antara IMTAQ dan IPTEK}

Persoalan lain yang muncul dalam era globalisasi ini adalah adanya pengkotak-kotakan pendidikan. Pada satu sisi lembaga pendidikan lebih mengutamakan Ilmu Pengetahuan dan Teknologi (IPTEK), dan pada sisi lain lebih mengutamakan segi ilmu iman, dan takwa (IMTAQ). Dikotomi tersebut telah membawa kepada kondisi di mana masyarakat peserta

${ }^{64}$ Alif Cahya Setiyadi, "Pendidikan Islam dalam Lingkaran Globalisasi”. Jurnal At-Ta'dib. Vol. 7 No. 2 2012, h. 247.

${ }^{65} \mathrm{Ibid}$, h. 247-248. 
didik lebih menguasai ilmu pengetahuan umum akan tetapi lemah dalam segi ilmu agama dan sebaliknya. Kondisi ini sangat mengkhawatirkan dan berakibat pada terbentuknya generasi yang berpribadi besi dan bermoral rendah karena terhegemoni oleh iptek. Sementara generasi lainnya memiliki integritas moral yang baik tetapi miskin ilmu pengetahuan dan teknologi.

Pola dikotomis sistem pendidikan modern tersebut telah membawa kepada sistem yang mengedepankan transfer of knowledge and skill di satu sisi dan transfer knowledge and value. ${ }^{66}$ Adanya dikotomis sistem pendidikan tersebut terlihat jelas di era modern dengan munculnya lembaga-lembaga pendidikan yang benar-benar membangun kemampuan kognitif peserta didik dengan mengorbankan segi etika. Sekolah SBI ataupun RSBI menjadi bukti nyata dan jelas akan dikotomis sistem pendidikan tersebut. Sudah tidak ada lagi kesimbangan di dalamnya, etika menjadi timbangan yang ringan sedangkan pencekokan berbagai ilmu pengetahuan umum yang mengarahkan pada aspek kognitif memiliki timbangan yang lebih berat. Sehingga timbangan keadilan pendidikan terlihat "njomplang", tidak seimbang dan berat sebelah. ${ }^{67}$

\section{c. Perubahan Orientasi}

Adanya pembedaan imtaq dan iptek dalam sistem pendidikan di era global ini telah membawa kepada perubahan orientasi pendidikan. Pendidikan saat ini lebih mementingkan usaha untuk merubah peserta didik menjadi pribadi superior dalam hal akal dan praktis, lemah dalam hati. Pribadi yang benar-benar disiapkan sebagai pemegang kasta baru

${ }^{66}$ Ibid, h. 248.

${ }^{67}$ Ibid, h. 248-249. 
dalam pendidikan sebagai pribadi yang memegang kendali atas mereka yang kurang cerdas dan mereka yang miskin. Mereka tidak lagi dididik untuk dapat mengendalikan kesenjangan antara yang cerdas dan yang kurang, antara yang kaya dan yang miskin, dan sebagainya. Mereka yang kaya akan memiliki banyak kesempatan untuk menjadi cerdas, sedangkan si miskin semakin terlantar dengan kebodohan.

Peningkatan kualitas pendidikan dalam rangka menghadapi globalisasi dengan langkah-langkah modern yang diambil di atas tidaklah merupakan orientasi pendidikan yang sesuai dengan Islam dan bahkan budaya lokal bangsa ini. Islam dan budaya Indonesia berorientasi kepada proses pembelajaran, tidak pada hasil. Proses disini menyeluruh dalam segala segi kehidupan manusia, tidak membebani peserta didik dengan jumlah kemampuan yang harus dipenuhi, tidak membawa mereka pada keadaan berfikir terus menerus untuk dunia, dan lain sebagainya.

Upaya ini telah mempersempit makna pendidikan menjadi urusan persekolahan saja. Sekolah dapat dianggap berkualitas dan diakui dunia apabila berbahasa pengantar bahasa Inggris dan berlabel internasional. Dengan ini berarti lembaga pendidikan telah mematikan potensi lokal dengan mengedepankan franchise kurikulum asing. Kurikulum asing diterapkan dengan jumlah yang dominan sehingga lambat laun peserta didik tercerabut dari akar budanyanya karena kehilangan system nilai dan ide adiluhungbangsa dan Islam. ${ }^{68}$

\section{d. Krisis Moral dan Kepribadian}

Perubahan orientasi pendidikan modern yang sudah jauh dari nilai budaya local dan pendidikan Islam ini telah menimbulkan krisis moral dan kepribadian. Bagaimana hal ini tidak terjadi apabila pendidikan 
menganaktirikan moral dan kepribadian dalam pola pendidikan yang dilakukan. Kurikulum, materi, proses, dan semua yang terlibat dalam pendidikan modern tersebut sedikit memiliki element moral atau bahkan tidak. Moral dan kepribadian menjadi sesuatu yang benar-benar dikesampingkan karena dianggap tidak akan membawa kepada "keberhasilan" yang dicita-citakan. ${ }^{69}$

\section{Tantangan Dan Peluang Pendidikan Islam Di Era Globalisasi}

Keberhasilan suatu pembangunan termasuk pendidikan selalu disertai dengan tantangan-tantangan baru dan bahkan dampak negatifnya sekaligus. Sebagai antisipasi diperlukan respon dan perlakuan baru yang lebih baik, termasuk dalam hal pendidikan Islam sangat diperlukan konsep pendidikan baru yang lebih Islami. Upaya mencari paradigma baru pendidikan semakin menjadi obsesi semua kalangan, karena seluruh proses kehidupan identik dengan proses pendidikan. Di samping itu, urgensi mencari dan menemukan paradigma pendidikan baru yang semakin islami itu ditentukan pula oleh kondisi objektif dunia saat ini di mana moral telah benar-benar dikesampingkan sebagai bagian esensial dari kehidupan manusia. ${ }^{70}$

Dalam kaitan dengan persoalan di atas, maka tantangan yang bersifat mendasar terhadap sistem pendidikan Islam antara lain: ${ }^{71}$

a. Mampukah sistem pendidikan Islam menjadi centre of excellence bagi perkembangan ilmu pengetahuan dan teknologi (IPTEK) yang tidak bebas nilai.

b. Mampukah sistem pendidikan menjadi agen pembaruan pemikiran Islam yang responsif terhadap tantangan zaman tanpa mengabaikan aspek dogmatis yang wajib diikuti.

\footnotetext{
${ }^{69}$ ibid, h. 250.

${ }^{70}$ M. Ali Sibram Malisi, op. Cit., h. 2-3

${ }^{71}$ ibid, h. 3
} 
c. Mampukah Pendidikan Islam menumbuh kembangkan kepribadian yang benar-benar beriman dan bertakwa kepada Allah lengkap dengan kemampuan bernalar ilmiah yang tidak mengenal batas akhir.

Tantangan yang dihadapi oleh pendidikan Islam harus diantisipasi agar pendidikan bisa dilaksanakan dan diimplementasikan sesuai dengan misi dan tujuannya. Jika suatu tantangan mampu diantisipasi atau dihadapi dengan baik, seringkali tantangan itu menjadi peluang yang sangat berdaya guna,sebaliknya jikatidak mampu dihadapi dengan baik, seringkali ia menjadi kendala yang sangat mengganggu upaya pelaksanaan dan implementasi misi dan tujuan pendidikan Islam.

Tantangan lainnya yang dihadapi pendidikan Islam adalah berkaitan dengan dampak yang ditimbulkan oleh globalisasi dunia yang didukung oleh kemajuan ilmu pengetahuan dan teknologi, khususnya teknologi informasi dan komunikasi (IPTEK). Pendidikan Islam mampu melahirkan manusia yang berorientasi ke masa depan, bersikap progresif, mampu memilih dan memilah secara baik, dan membuat perencanaan dengan baik.

Abuddin Nata mengemukakan tantangan yang dihadapi pendidikan Islam di era kekinian menghadapi pertarungan ideologi besardunia ditandai oleh lima kecenderungan sebagai berikut :

a. Kecenderungan integrasi ekonomi yang menyebabkan terjadinya persaingan bebas dalam dunia pendidikan. Munculnya konsep pendidikan yang berbasis padasistem dan infra-struktur, manajemen berbasis mutu terpadu (TQM), interpreneuruniversity dan lahirnya Undang-undang Badan Hukum Pendidikan (BHP) tidak lain, karena menempatkan pendidikan sebagai komoditi yang diperdagangkan.

b. Kecenderungan fragmentasi politik yang menyebabkan terjadinya peningkatan tuntutan dan harapan dari masyarakat. Kecenderungan ini 
terlihat dari adanya pengelolaan manajemen pendidikan yang berbasis sekolah (school based manajemen), pemberian peluang kepada komite atau majelis sekolah/madrasah untuk ikut dalam perumusan kebijakan dan program pendidikan, pelayanan proses belajar mengajar yang lebih memberikan peluang dan kebebasan kepada peserta didik, yaitu model belajar mengajar yang partisipatif, aktif, inovatif, kreatif, efektif dan menyenangkan (Paikem).

c. Kecenderungan penggunaan teknologi tinggi (high technologie) khususnya teknologi komunikasi dan informasi (TKI) seperti komputer. Kehadiran TKI ini menyebabkan terjadinya tuntutan dari masyarakat untuk mendapatkan pelayanan yang lebih cepat, transparan, tidak dibatasi waktu dan tempat.

d. kecenderungan munculnya penjajahan baru dalam bidang kebudayaan (newcolonization in culture) yang mengakibatkan terjadinya pola pikir (mindset) masyarakat pengguna pendidikan, yaitu dari yang semula mereka belajar dalam rangka meningkatkan kemampuan intelektual, moral, fisik dan psikisnya, berubah menjadi belajar untuk mendapatkan pekerjaan dan penghasilan yang besar.

Saat ini sebelum seseorang belajar atau masuk kuliah misalnya, terlebih dahulu bertanya: nanti setelah lulus bisa jadi apa? Dan berapa gajinya?.Program-program studi yang tidak dapat menjawab pertanyaan tersebut baik secaralangsung maupun tidak langsung, dengan sendirinya akan terpinggirkan atau tidak diminati. Sedangkan program-program studi yang menawarkan pekerjaan danpenghasilan yang baik bagi lulusannya akan sangat diminati. Tidak hanya itu, kecenderungan penjajahan baru dalam bidang kebudayaan juga telah menyebabkan munculnya budaya pop atau budaya urban, yaitu budaya yang serba hedonistik, materialistik, rasional, ingin serba cepat, praktis, pragmatis dan instans. Kecenderungan 
budaya yang demikian itu menyebabkan ajaran agamayang bersifat normatif dan menjanjikan masa depan yang baik (di akhirat) kurang diminati.

\section{Peluang Pendidikan Islam di Era Globalisasi}

Peluang pendidikan Islam seharusnya bisa ditangkap, diraih dan dimanfaatkan oleh para pemerhati pendidikan dalam rangka pelaksanaan dan implementasi nilai dan tujuan untuk menyongsong masa depan yang penuhkompetisi ditandai dengan munculnya eraglobalisasi. Adapun peluang pendidikan Islam bisa dideskripsikan di antaranya: ${ }^{72}$

a. Peningkatan fungsi dan peranan. Seperti kita ketahui beberapa tahun belakangan fungsi dan peran pendidikan Islam sangat terbatas, dan kadang-kadang terjadi diskriminasi. Outputnya tidak dapat diterima pada jenjang tertentu atau kemampuannya diragukan pada lapangan kerja tertentu. Namun sejak diberlakukannya UU No. 20 Tahun 2003 tentang Sistem Pendidikan Nasional dengan berbagai peraturan penjabarannya, fungsi dan peran lembaga pendidikan Islam mulai dari tingkat dasar hingga perguruan tinggi sudah diperluas bahkan sudah terbuka lebar. Karena itu, peluang ini harus diraih dan didayagunakan oleh segenap potensi penyelenggara pendidikan Islam.

b. Peningkatan persaingan dan antisipasi agama. Selaras dengan era globalisasi, dimana pemikiran manusia semakin kompleks dan menimbulkankebingungan dalam masyarakat, perlu adanya pendekatan sosialisasi dan internalisasi nilai-nilai agama.

c. Kerjasama. Di era globalisasi yang penuh kompetisi, sangat sulit bagi suatu lembaga pendidikan dapat berjalan dan berkembang sendiri tanpa mau terlibat dan melibatkan pihak lain. Ini berarti solusi utamanya adalah

${ }^{72}$ ibid, hlm. 6-7. 
harus mampu menciptakan kerjasama kelembagaan yang saling menguntungkan.

\section{Implikasi Globalisasi terhadap Pendidikan Islam}

Globalisasi yang sering diterjemahkan "mendunia". Segala apapun yang terjadi di dunia begitu cepatnya menyebar di seluruh pelosok baik berupa data, temuan-temuan, bencana, atau peristiwa apapun. Semua orang di dunia bisa mengetahui semua itu melalui berbagai media seperti HP, TV, Radio. Malahan sekarang ada yang lebih canggih yaitu internet.

Azyumardi Azra mengatakan "pendidikan Islam merupakan pendidikan manusia seutuhnya, akal dan ketrampilan dengan tujuan menyiapkan manusia untuk menjalani hidup dengan lebih baik". Namun hal itu tidak berjalan dengan lurus, karena pendidikan Islam dipengaruhi oleh arus globalisasi yang terjadi saat ini. Globalisasi merupakan ancaman besar bagi pendidikan Islam untuk mempertahankan nilai-nilai agama yang murni. $^{73}$

Mengenai dampak dari globalisasi Qodri Azizy mengemukakan, Globalisasi merupakan sebuah fenomena yang banyak menimbulkan dampak negatif yang dibawa oleh negara-negara Barat (terutama Amerika Serikat) dengan tujuan agar masyarakat mengikuti cara hidup di negara mereka. Efek-efek negatif tersebut di antaranya pemiskinan nilai spiritual, jatuhnya manusia dari makhluk spiritual menjadi makhluk material, dan peran agama digeser menjadi urusan akhirat sedang urusan dunia menjadi wewenang sains (sekularistik). ${ }^{74}$

Dengan demikian arus globalisasi bisa berdampak positif dan sekaligus negatif terhadap laju pendidikan Islam. Akan berdampak positif jika pendidikan Islam mampu memaknai secara proporsional terhadap

\footnotetext{
${ }^{73}$ Arif Shaifudin, op., cit, h. 224

${ }^{74}$ Ibid, h. 224.
} 
globalisasi dan akan berdampak negatif manakala pendidikan Islam tidak responsif atau bahkan konservatif terhadap arus globalisasi yang tidak mungkin dapat dihindarkan dalam dinamika sosial sekarang ini.

\section{Tanggapan Umat Islam Terhadap Globalisasi Dan Modernisasi}

Untuk memahami respons masyarakat terhadap modernitas, barangkali harus didudukan terlebih dahulu apa yang dimaksud dengan istilah "respons masyarakat", agar tidak terlalu bias. Jadi, respons masyarakat yang dimaksudkan di sini adalah pandangan atau reaksi para tokoh masingmasing agama terhadap kemodernan. Ada yang beranggapan bahwa agama pada umumnya merupakan penghambat modernisasi. Sebaliknya, mungkin juga disebabkan oleh model modernisai barat yang ditawarkan hanya berorientasi pada keduniawian semata, sehingga nilai-nilai spiritual ditinggalkan. Seakan-akan Barat tetap merupakan model yang tak dapat dihindari. Demikian pula sikap merendahkan sesuatu yang berkaitan dengan hal-hal yang tua (termasuk orang tua), masa lalu dan tradisi. ${ }^{75}$

Problem modernisasi tidak hanya dihadapi oleh golongan tertentu, atau satu agama saja, namun juga dihadapi oleh agama-agama lain, seperti Yahudi, Kristen dan Islam. Secara sederhana, fenomena ini disebabkan, agama-agama tersebut harus memilih di antara dua pilihan; sejalan dengan zaman modern, atau mati. ${ }^{76}$

Dari ungkapan tersebut, menunjukkan betapa agama dihadapkan kepada delematis dalam menyikapi kemodernan. Sesungguhnya, usaha agama untuk mewujudkan kesesuaian dengan peradaban barat dan memberikan penyelesaian terhadap problem besar yang sedang dihadapi. Di dalam pemikiran keagamaan besar, gerakan pembaruan keagamaan dikenal dengan istilah modernisme.

\footnotetext{
${ }^{75}$ Ibid, h. 277

${ }^{76}$ ibid
} 
Jadi, modernisme merupakan gerakan yang berusaha menundukkan prinsip-prinsip masyarakat beragama di bawah nilai-nilai dan pemahaman peradaban Barat, berikut konsepsi serta visinya dalam berbagai bidang kehidupan. Berangkat dari berbagai tanggapan, pendapat dan reaksi para pemikir dan agamawan terhadap modernitas dan kemodernan, maka menarik untuk ditelaah lebih dalam bagaimana respons Kristen dan Islam terhadap modernitas tersebut.

\section{Upaya Pendidikan Islam Menciptakan Lembaga Yang Unggul Di Era}

\section{Globalisasi}

Dalam mengoptimalkan serta memodernisasi lembaga pendidikan Islam secara serius dimasa kini beberapa kemungkinan yang dapat dilakukan yakni:

\section{Membangun Kepercayaan Masyarakat Terhadap Pendidikan Islam}

Lembaga pendidikan adalah lembaga yang dibangun di atas cita-cita masyarakat. Sehingga segala program-program yang telah dicanangkan diketahui oleh siswa dan masyarakat sekitar. Hal ini penting diketahui agar tidak terjadi keresahan pengguna pendidikan pada saat dan sesudah terjadinya proses pembelajaran. Di samping itu, masyarakat juga memiliki tanggung jawab dalam mendukung kesuksesan programprogram yang telah disusun lembaga pendidikan. Lembaga pendidikan yang mempunyai kontak hubungan yang baik dengan masyarakat, akan terus maju.

Lembaga Pendidikan Islam harus mempunyai standar mutu yang diinginkan dan program-program mutu yang ditawarkan kepada masyarakat pengguna lembaga pendidikan. Program-program mutu ini harus disertai dengan standar mutu yang telah ditetapkan serta perlu adanya perencanaan stategis dan profesionalitas SDM yang menjalankan program-program mutu tersebut.

68 


\section{Merancang Kurikulum Yang Sesuai Dengan Kebutuhan Masyarakat}

Lembaga pendidikan Islam seharusnya memiliki kurikulum yang didasarkan pada pandangan tentang tidak adanya dikotomi antara ilmu agama dan ilmu umum, dunia dan akhirat. kurikulum ini terus dikembangkan dari waktu ke waktu sejalan dengan tuntutan masyarakat, perkembangan ilmu pengetahuan dan teknologi, serta tuntutan dunia kerja. dengan demikian, terjadi hubungan yang sinergis antara lembaga pendidikan Islam dengan masyarakat.

\section{Mencetak Lulusan Yang Memiliki Daya Saing Tinggi}

Untuk mencetak output yang memiliki daya saing tinggi, harus didukung oleh proses belajar mengajar yang berbasis pada pemberdayaan para siswa (studentcentris), yaitu proses pembelajaran yang lebih interaktif, inspiratif, menggairahkan, menantang, memotivasi siswa untuk aktif, menumbuhkan prakarsa, kreativitas, kemandirian, sesuai dengan bakat dan minat, serta memberi keteladanan. Melalui proses belajar mengajar yang demikian, diharapkan dapat melahirkan lulusan yang unggul, terberdayakan, serta penuh percaya diri.

\section{Memiliki sarana dan prasarana yang memadai serta meningkatkan daya saing melalui IPTEK}

Lembaga Pendidikan Islam memiliki sarana dan prasarana sesuai standar pendidikan nasional yang baik. Misalnya ruang belajar yang baik dan mencukupi, tempat olahraga, tempat ibadah, perpustakaan, laboratorium, serta sumber belajar lainnya yang menunjang proses pembelajaran termasuk penggunaan teknologi informasi dan komunikasi. Selain itu, untuk meningkatkan daya saing lembaga Pendidikan Islam dalam menghasilkan karya-karya bermutu sebagai hasil penguasaan ilmu pengetahuan dan teknologi, harus dimulai dari memperbaiki mutu 
lembaga Pendidikan Islam secara terus-menerus agar bisa memenuhi tuntutan dan kebutuhan masyarakat secara luas

\section{Kesimpulan}

Hadirnya globalisasi dalam kehidupan pribadi dan sosial kita, maka setiap perjalanan hidup dipaksa menerima warna globalisasi. Tidak terkecuali dengan sistem pendidikan Islam di era modern ini. Pendidikan Islam dihadapkan pada berbagai persoalan yang memberikan dampak yang cukup signifikan terhadap produk output pendidikan Islam. Di antara tantangan yang kelihatan jelas adalah konformisme, dikotomi IMTAQ dan IPTEK, dekadensimoral dan sebagainya.Untuk itu perlu bagi pendidikan Islam kembali memperkuat sistem pendidikan Islam baik secara konseptual maupun praktis.

Tantangan dunia pendidikan Islam di era global dewasa ini adalah tidak tersedianya SDM yang memadai sehingga memerlukan upaya-upaya dalam pengembangan mutu pendidikan yang unggul dan kompetitif dalam merespon arus modernisasi dan otonomisasi. Upaya-upaya tersebut dapat dipersiapkan melalui kaderisasi melalui jenjang pendidikan S2 dan S3 termasuk pelatihan-pelatihan yang dapat meningkatkan keterampilan dalam arti yang luas. Dengan demikian maka tantangan otonomisasi dan globalisasi akan dapat dijadikan peluang-peluang dalam meresponnya.

\section{Referensi}

Arif Shaifudin. 2016. "Peran Strategis Pendidikan Islam di Era Globalisasi”. Al-Hikmah Jurnal Studi Islam. Vol. 6 No. 2.

Alif Cahya Setiyadi. 2012. "Pendidikan Islam dalam Lingkaran Globalisasi”. Jurnal At-Ta'dib. Vol. 7 No. 2.

M. Ali Sibram Malisi. 2017. "Tantangan dan Peluang Pendidikan Islam di Era MEA”. Jurnal Transformatif (Islamic Studies). Vol. 1 No. 1. 
Ali Mahsun. 2013. "Pendidikan Islam dalam Arus Globalisasi; Sebuah Kajian Deskriptif Analitis”. Jurnal Episteme Vol. 8 No. 2.

M. Ali Sibram Malisi. 2017 “Tantangan dan Peluang Pendidikan Islam di Era MEA”. Jurnal Transformatif (Islamic Studies). Vol. 1 No. 1

Nurcholish Madjid. 1992 "Islam Doktrin dan Peradaban; Sebuah Telaah Kritis Tentang Masalah Ketuhanan, Kemanusiaan, dan keindonesiaan”. Jakarta: Paradima.

Nurcholish Madjid. 1987 "Islam dan Kemodernan dan Keindonesiaan". Bandung: Mizan.

Harun Nasution. 1995 "Islam Rasional Gagasan Dan Pemikiran”. Bandung: Mizan. 